\title{
SOCIAL-ECONOMIC ADAPTATION STRATEGIES OF BAJO MOLA FISHERS IN WAKATOBI NATIONAL PARK
}

\author{
MARLINA* \\ Universitas Negeri Malang, Faculty of Social Science, Geography Department, Indonesia, e-mail: marlinamalaia@gmail.com \\ SUMARMI \\ Universitas Negeri Malang, Faculty of Social Science, Geography Department, Indonesia, e-mail: sumarmi.fis@um.ac.id
}

I Komang ASTINA

Universitas Negeri Malang, Faculty of Social Science, Geography Department, Indonesia, e-mail: komang.astina.fis@um.ac.id

Singgih SUSILO

Universitas Negeri Malang, Faculty of Social Science, Geography Department, Indonesia, e-mail: singgih.susilo.fis@um.ac.id

\begin{abstract}
Citation: Marlina, Sumarmi, Astina, I.K., \& Susilo, S. (2021). SOCIAL-ECONOMIC ADAPTATION STRATEGIES OF BAJO MOLA FISHERS IN WAKATOBI NATIONAL PARK. GeoJournal of Tourism and Geosites, 34(1), 14-19. https://doi.org/10.30892/gtg.34102-613
\end{abstract}

\begin{abstract}
Considering the fulfillment of coastal communities' needs and welfare must be prioritized by the Wakatobi National Park manag ement. The study aimed to describe the social adaptation of Bajo Mola community in the Wakatobi National area. The research method used descriptive qualitative with data collection through observation, in-depth interviews, documentation and literature review and analysed using triangulation models. The results showed Bajo Mola is one of the communities that lives depend on the sea. The total number of Bajo Mola fi shers is 3,358 of 8,048 total people $(41.72 \%)$. Based statistics data certain impacts on marine conservation, but the Wakatobi National Park area also has impacts on the socio-economic growth of the community. That Bajo Mola community interpreted the sea as a source of life. Since the regional autonomy formed on Wakatobi Regency and appointed as the Wakatobi National Park, the management has encouraged the community to be more creative using the marine resources. Even though traditional fisherman was still developing until now, the businessmen with the aquaculture innovations have supported the community to get the maximum profit. The strategy used was by processing dried fish, grouper farming, and having loing technology. Farming activities and loing technology have a positive impact on the Bajo community by facilitating fishers to sell their catch. Also, marketing access directs to be more extensive in foreign countries.
\end{abstract}

Key words: socio-economic adaptation, Bajo Mola, Wakatobi National Park

$* * * * *$

\section{INTRODUCTION}

Humans can exploit natural potential in various ways to support the socio-economic welfare of the community. Economic activities by humans can form patterns of adaptation even to the coastal environment. The United Nations estimates that more than 600 million people (10\%) of the world's population live in coastal areas and 2.4 billion people (40\%) live within $100 \mathrm{~km}$ of the coast (United Nations, 2017). Coastal populations also depend on fishing at sea and harvesting land products for food needs, in cooperation with groups from the land, and that archipelago state consumes fish more than the public in general (Cisneros-Montemayor et al., 2016). Numbers showed the high dependence of the community on marine products that cause people to try to adapt for survival. According to Geertz (1981:42), the community dependence on sea products provides a distinct identity for coastal communities with certain lifestyles known as coastal culture communities. People as cultured beings in which culture is formed from the results of human creations, works and initiative. One of the main factors that form culture is the natural factor, the situation and condition of the natural environment indirectly shape the character of the people's personality, ecological intelligence, culture and traditions. Bakker revealed (1984:22) that culture is the creation, control and processing of human values of "man humanizes Himself in humanizing the world around him". The statement means the way humans use natural products or the environment, such as the physical environment and social environment, then developed so that it can obtain higher profits. Conducting conservation activities on nature and interacting perfectly between human beings as an integrated element (Moeis, 2008).

A culture that is formed physically by nature begins when humans settle in a place, so then created a group of people called a farming community and a fishing community (Koentjaraningrat, 1990). Common farming communities stayed in rural areas, while fishing communities stayed in coastal areas. In further developments, life was increasingly becoming more complex and diverse, and with many people discovered kinds of material and life support tools and their relationships with various other societies (Moeis, 2008).

Many Indonesian people live in the coastal community. Becoming a coastal community does not set automatically, but there is a potential that can be explored and used by individuals. The use of coast and sea is quite diverse, such as fish farming and other tourism potentials. Many areas can implement tourism based on the marine potential to encourage blue economy, including the empowerment of the Klatak Beach community by three fisher groups: Mina Klatak, Rayap Pereng, and Pereng Mania. The policies of fishermen groups and the Tulungagung Regency government have supported the creation of a blue economy (Sumarmi et al., 2020).

One of the tribes who use as a coastal community and known as the sea gipsy is the Bajo community. The Bajo people adapt to their environment in unusual ways of looking at the coast and the sea. Bajo people interpret the sea not only as a place to live and make a living but also as a place for their ancestor's spirits. Bajo people have a unique maritime culture system, which if traced, studied and developed can be adapted to the management of marine and marine resources (Wani and Ariana, 2018; Bennet, 2019). The interrelated relationship between the Bajo and the sea illustrates the ecological adaptation of the community in the management of the Nat ional Park area. The assumption that a sea is a place where their brothers create functional and emotional relations to the sea is as the functional

\footnotetext{
${ }^{*}$ Corresponding author
} 
relationship that is shown by the way the Bajo people understand the concept of sustainability for marine conservation. Bajo people consider the idea of sustainability by believing in God and have encouraged their self-conscious behaviour to manage existing resources. Another study finds that the Bajo tribe has a good arrangement in capturing the location of fishing area based on group behaviour (Bahtiar, 2012). The sustainability of the Bajo tribe in protecting marine resources is supported by regulating fishing time and the use of traditional boats called "Leppa or Sopek" (Artanto, 2017). Portraits of Bajo life were found on the coast of the Wakatobi archipelago, with the most community being on the coast of the fragrant island better known as the Bajo Mola community. The Bajo Mola community currently stands at 7,035 (BPS, 2019). A large number of residents can see the great potential of marine and fisheries so that it can have an impact on resource exploitation. The emergence of various cases that have not yet been resolved was destructive, illegal fishing, sand mining, visitors, fishing businesses, ineffective management of tourism, overexploitation of resources and technical problems such as government policies in conservation (Dirhamsyah, 2016; Sopari et al., 2014; Khasanah et al., 2019; Lewin et al., 2019).

Staying at Wakatobi National Park area with a large number of natural resources makes Bajo Mola people are required to partic ipate in conserving the area. As an area with abundant natural resource potential, the preservation of the Wakatobi National Park needs to be done immediately. Eccording Turak (2003), quoted in Firmansyah et al., (2016) the potential has been exploited as a world biosphere reserve. Wakatobi is a biodiversity hotspot that has a function as a supplier of larvae for fish resources (SDI) and marine biodiversity (KHL). Also, to protect the area, it was appointed as a National Park and biosphere reserve in Indonesia (UNESCO, 2012). The establishment and zoning system certainly can have an impact on the economic activities of the community. The study needs to ass ess the socio-economic impact and community adaptation strategies to the selection of TNW.

\section{METHOD}

The study used descriptive qualitative methods with data collection techniques through observation, in-depth interviews, documentation and literature review. The study was conducted on the Bajo Mola community in Wakatobi Regency, Indonesia. The data were obtained from Bajo Mola fishers and local government. Data analysis was completed with a triangulation model to study the socioeconomic adaptation strategy of the Bajo Mola community in the Wakatobi National Park area. To collect data, researchers interacted with informants or participants then reported the observation. The data analysis was obtained through the informants' answers based on the research focus. A qualitative researcher must analyze data from the beginning and avoid accumulating or collecting everything (Fatchan, 2015). Furthermore, the data analyzed based on observation, in-depth interviews, and documentation. The data analysis was used interactive data analysis by Miles and Huberman (1994) quoted in Moleong (2016), which is data reduction, data presentation, and conclusion. The research location can be seen in the following Figure 1. The research location can be seen in the following Figure 1.

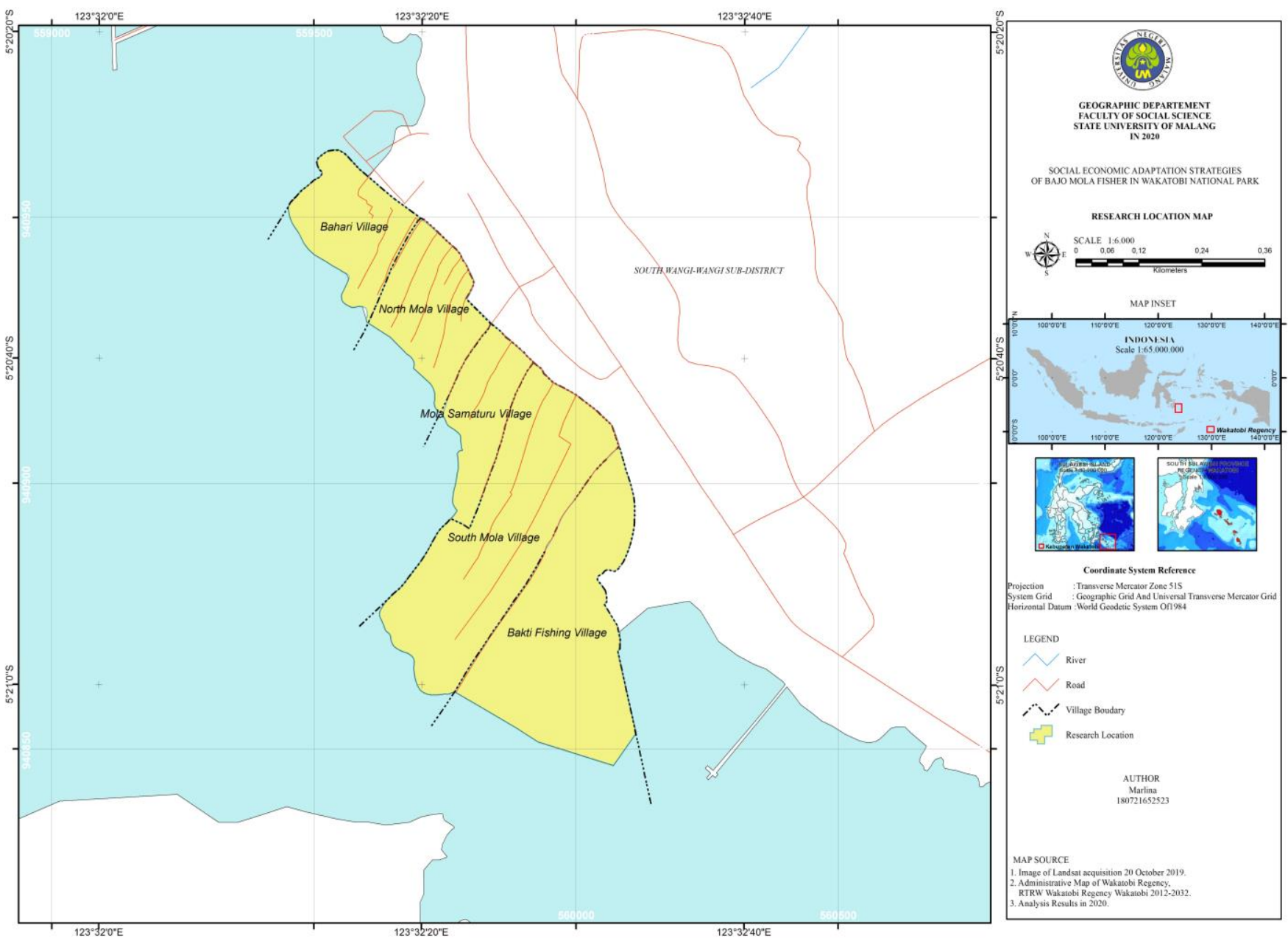

Figure 1. Location of Bajo Mola village, Wakatobi regency (Source: Map by Results of the research)

\section{RESULTS AND DISCUSSION}

Bajo Mola community in Wakatobi Regency are divided into 5 villages that are Bakti Fishing village, South Mola village, Mola Samaturu village, North Mola village and Mola Bahari village. The five villages are better known as Mola village or Bajo village in the 
South Wangi-Wangi sub-district area. Based on the map (Figure 1) Mola village is an area on the coast of $\pm 8.3 \mathrm{Km}^{2}$ with the following boundaries; (1) the north side is bordered by the sea, (2) the east is bordered by Mandati III village, (3) the south is bordered by the sea and (4) the west is bordered by the Otowwe Island strait.

Physically Bajo Mola village is located on the coast of Mandati as reclamation area. The reclamation comes from a pile of rocks collected by residents through coral mining. This sea reclamation was carried out since the 1970s which resulted in reclamation, then made "land" and constructed residential area. Because of it, the Mola village area has an evenly distributed topography throu ghout the region of around 1-2 meters above sea level, which is relatively flat (between 0\% - 5\%). Climatology Conditions Mola Village is divided into two seasons that are the dry season (East season) which runs between April - August and the rainy reason (West season) which lasts from September to April with a daily temperature of $19^{\circ}-34^{\circ} \mathrm{C}$ (BMKG, 2020). As bio-ecologically, the waters of the Mola consist of several important ecosystems, such as seagrass and coral reefs, as well as various types of marine life such as baronang fish, crabs, sea cucumbers, shellfish and other small fish. Recent data showed the rapid growth of Bajo people in Mola village so that it is proposed to become a new sub-district on Wangi-Wangi Island. Bajo Mola people have experienced many changes in their lifestyle, livelihood and rituals. Though The Bajo Mola area was divided into 5 villages, it does not reduce the uniqueness, characteristics, and culture and uniqueness of the Bajo people in each area. The division is only an attempt by the government to facilitate administration.

\section{A. The economic conditions of the Bajo Mola community}

Human life cannot be separated from its environment. It is because environmental factors have a major influence on human life. Deterministic adaptation explains how nature greatly influences humans who are very dependent on nature (Marlina et al., 2020). One example of deterministic adaptation is illustrated by the life of the Bajo Mola community in Wakatobi Regency, which is portrayed in the socio-economic aspect. Based result of research from the socio-economic point of view, the adaptation pattern of Bajo Mola people is shown by the dominance of $98 \%$ working as fishers. It is the only choice for Bajo people as fishing is a natural skill so that fishers are automatically the primary profession for Bajo people. For Bajo people working as fishers was begun since they were children so that the profession is gained from the experience of going to sea early on from their parents. The results of interviews with some fis hing communities said that being a fisherman has a fairly economic impact, and the community's income is quite high. It is aligned with the data of 2019, showed a total of 3,358 people working as fishers (BPS, 2020). Mola village is a village based on maritime activities and fisheries. Most of Mola villager was working as fishers. The village was strived to be more advanced to improve the standard of living of the community. Therefore, it could impacts on the welfare of the population both facilities and infrastructure. Working as a fisherman is not only carried out by men, but some women often accompany and help their husband's work such as crafting, archery and provi ding fishing equipment and helping to find the bait. The types of occupation of the Bajo Mola community was shown in the following Table 1 .

Table 1. The types of occupation of the livelihoods of the Bajo Mola Community (Source: Profile of 5 Bajo Mola villages, 2020)

\begin{tabular}{|c|c|c|c|c|c|c|c|c|}
\hline \multirow[b]{2}{*}{ No } & \multirow[b]{2}{*}{ Occupation } & \multicolumn{5}{|c|}{ Village } & \multirow[b]{2}{*}{ Total } & \multirow[b]{2}{*}{$\%$} \\
\hline & & Mola Selatan & Mola Utara & Mola Samaturu & Mola Bahari & $\begin{array}{c}\text { Mola Nelayan } \\
\text { Bakti }\end{array}$ & & \\
\hline 1 & Fisher & 998 & 456 & 112 & 321 & 1.471 & 3.358 & $41.72 \%$ \\
\hline 3 & Service & 10 & 5 & - & - & 18 & 33 & $0.41 \%$ \\
\hline 4 & Civil servant (PNS) & 10 & 15 & 13 & 4 & 5 & 42 & $0.52 \%$ \\
\hline 5 & Police (TNI/POLRI) & 2 & 1 & - & - & - & 3 & $0.03 \%$ \\
\hline 6 & Unemployee & 1.049 & 560 & 871 & 975 & 1.025 & 4.480 & $55.7 \%$ \\
\hline & Total population & 2.095 & 1.052 & 1.038 & 1.308 & 2.554 & 8.048 & $100 \%$ \\
\hline
\end{tabular}

Based on data obtained from the village profile in 2019, the total number of Bajo Mola fishers was 3,358 out of a total population of $8,048(41.72 \%)$. In comparison, the number of Bajo people who have other types of work (not fishermen) is 204 people (25.5\%). Whereas the population that unemployed is 4,480 people $(55.7 \%)$ and categorized into 2 groups; 1 ) children from $0-14$ years old age group and 2) Bajo Mola people who are physically and mentally unable to work. The following is a graph of the livelihoods of the Bajo Mola community out of a total of five.

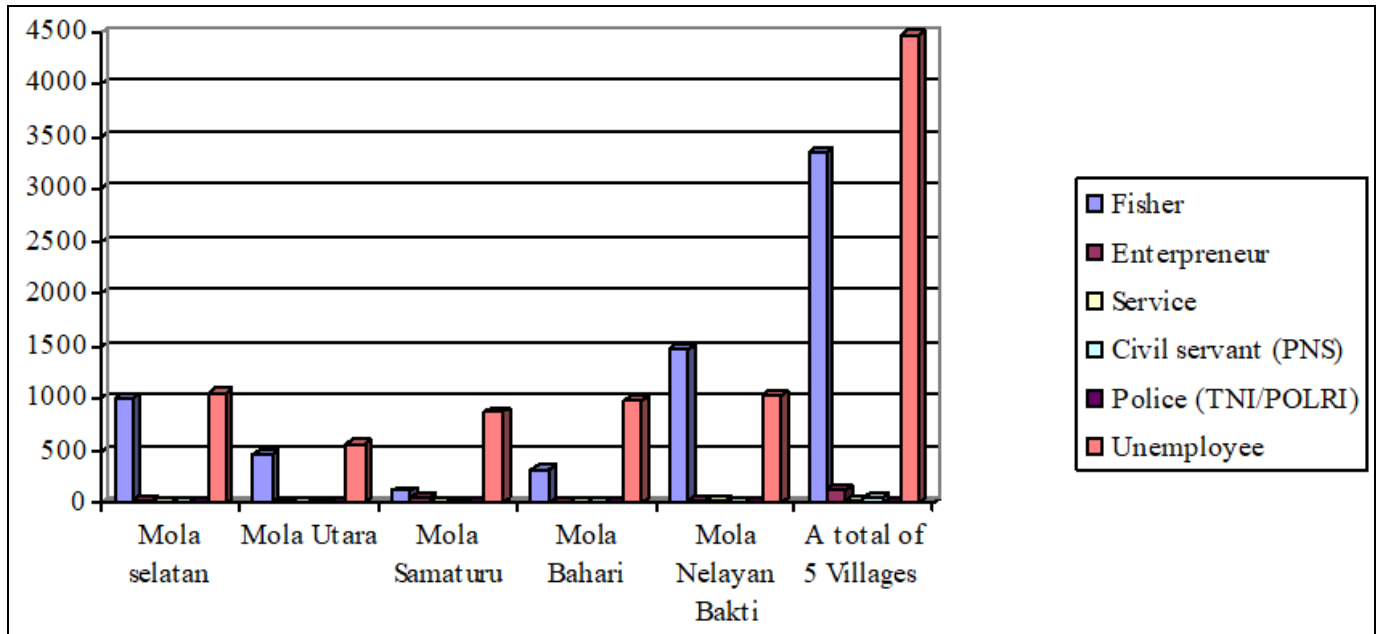

Figure 2. Graph of the livelihoods of the Bajo Mola Community (Source: Profile of 5 Bajo Mola villages, 2020)

\section{B. Socio-economic adaptation strategy}

The adaptation of the Bajo Mola community to its environment is shown by how the Bajo people perceive the sea. The sea for the Bajo 
people is like a garden full of resources that are always fruitful and ready to be harvested. The relation between the Bajo people and the sea also influences the knowledge and life patterns of the Bajo people, which almost all aspects of their lives are highly dependent on marine resources. It relates to the deterministic paradigm that the nature of culture created by humans is inseparable from the influence of physical environmental factors such as climate, topography, natural resources and regional geography.

Adaptation is interpreted as an adjustment of living things with their environment. Human interaction with the environment is a process of adaptation of how humans can survive the changes in the environment. Ecological adaptation is an adaptation that takes place on certain cultural elements which include socio-economic, socio-cultural, social organization and technology.

The adaptation process in the Bajo Mola community is the result of a transformation process due to the impact of environmental changes, government policies and people's life patterns on the selection of Wakatobi as the national park. There have been ma ny changes in adaptation to the Bajo Mola community from then until now. The rapid modernization and globalization also had a positive and negative impact on the lives of Bajo people. Bajo community adaptation has been going on for a long time until the selection of the Wakatobi islands as a national park area. Staying around the Wakatobi National Park was directly benefit for the Bajo Mola community. With abundant of marine products, the life of Bajo people who live in coastal areas has shaped the behaviour of Bajo pe ople who are very dependent on marine products. Nearly $90 \%$ of the people earn a living as fishers, such as tuna, reef, squid and others.

The profession as a fisherman has a diverse economic impact on the community. The socio-economic condition of Bajo people is described as a socio-economic of fishing communities. Bajo Mola people are a society that lives both traditionally and modernly. It can be seen from the interaction among the people, which is so full of togetherness, and the culture that developed in Mola Village. There have been many changes in the socio-economic aspects of the Bajo Mola community since the formation of regional autonomy in Wakatobi Regency and the selection of Wakatobi as a national park. It encourages people to use marine resources creatively. Although traditional fishers still exist today, the existence of entrepreneurs with aquaculture innovations can support community activities to get the maximum profit. The existence of a zoning system and supervision of TNW management also requires people to be creative to fill the daily needs.

Table 2. Ecological adaptation development of the Bajo Mola community in economic aspects (Sumber: Reseach result of 2019-2020)

\begin{tabular}{|l|l|l|l|l|l|}
\hline \multirow{2}{*}{ No } & \multirow{2}{*}{ Adaptation } & \multirow{2}{*}{$\begin{array}{l}\text { Life pattern } \\
\text { (nomaden) }\end{array}$} & $\begin{array}{l}\text { Stay at Mola } \\
\text { (1960an-1970an) }\end{array}$ & $\begin{array}{l}\text { Stay at Mola and fishing in } \\
\text { Arafuru, Flores and Australia } \\
\text { (1970-1990) }\end{array}$ & $\begin{array}{l}\text { Regional Autonomy if Wakatobi and selection } \\
\text { of Wakatobi National Park (1996- current) }\end{array}$ \\
\hline $\mathbf{1}$ & Occupation & $\begin{array}{l}\text { Overall as a } \\
\text { fisher }\end{array}$ & $\begin{array}{l}\text { As fisher and housewife } \\
\text { As retail of catches }\end{array}$ & $\begin{array}{l}\text { Some looking for alternative } \\
\text { businesses }\end{array}$ & $\begin{array}{l}\text { Some looking for alternative works, such as } \\
\text { business, but still on using marine resources, } \\
\text { also some as civil servants }\end{array}$ \\
\hline $\mathbf{2}$ & $\begin{array}{l}\text { Number of } \\
\text { catches }\end{array}$ & $\begin{array}{l}\text { Very } \\
\text { Abundant }\end{array}$ & Abundant & Enough & $\begin{array}{l}\text { Less, because of activity restrictions on certain } \\
\text { zones and patrols around the reef. }\end{array}$ \\
\hline $\mathbf{3}$ & $\begin{array}{l}\text { Price of } \\
\text { catches }\end{array}$ & $\begin{array}{l}\text { Low and just to } \\
\text { fill daily needs }\end{array}$ & $\begin{array}{l}\text { Pretty low, because of transaction } \\
\text { was based on trading goods. }\end{array}$ & $\begin{array}{l}\text { Enough, because Mola people } \\
\text { could trade with Mandati people }\end{array}$ & $\begin{array}{l}\text { High, because of wide interaction with people } \\
\text { outsite Mola, such as Mandate, Wanci, and aboard }\end{array}$ \\
\hline $\mathbf{4}$ & Marketing & Not yet done & $\begin{array}{l}\text { Limited, because transcation } \\
\text { was based on the person meet }\end{array}$ & $\begin{array}{l}\text { Open, trade network has } \\
\text { collaborate with suppliers }\end{array}$ & Wider \\
\hline $\mathbf{5}$ & $\begin{array}{l}\text { Distribution of } \\
\text { work function }\end{array}$ & Not yet done & Involved family member & $\begin{array}{l}\text { Involved distant relative, or } \\
\text { Sawi fishers }\end{array}$ & Contract labor \\
\hline $\mathbf{6}$ & $\begin{array}{l}\text { Relation with } \\
\text { exporter }\end{array}$ & Not yet done & Not yet done & Not yet done & Done, export to domestic and overseas \\
\hline $\mathbf{7}$ & $\begin{array}{l}\text { Relation with } \\
\text { bank or owner }\end{array}$ & Not yet done & Not yet done & Not yet done & Done \\
\hline
\end{tabular}

Based on Table 2 known that Bajo people have experienced many changes, especially in the economic aspects. The changes that are felt are the livelihood, the number of catches, the prices of catches, marketing, distribution of work functions, relations with exporters and relations with banks or owners. The socio-economic situation has changed the traditional Bajo community towards the modern of Bajo community. However, these changes have brought a better economic impact on the lives of Bajo people. Bajo Mola community activities in the socio-economic aspects are completed by selling the catch at the Mola Central market or selling it at the Wanci Night market. The Bajo women are known for selling their catches at lower prices compared to non-Bajo fishers (people outside Bajo village).

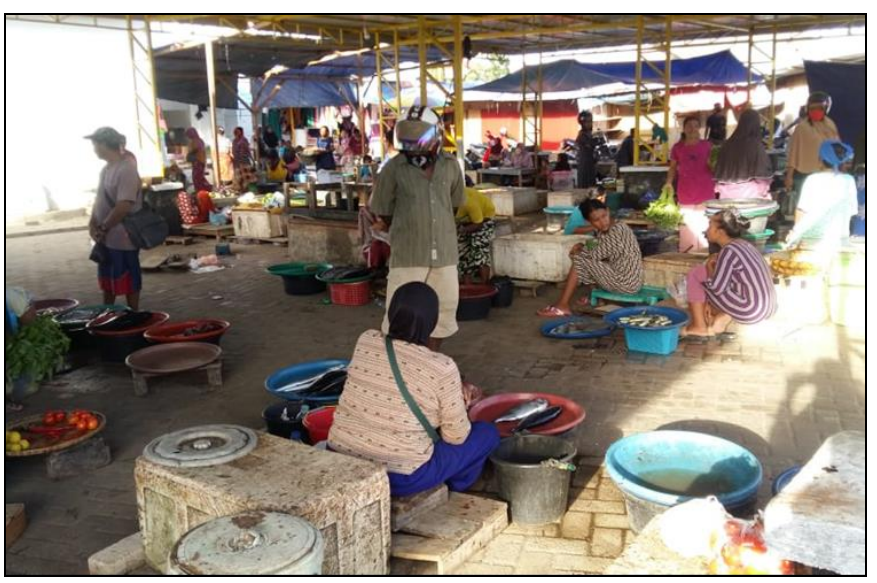

Figure 3. The economic activities of the Bajo Mola community in the Central Mola market

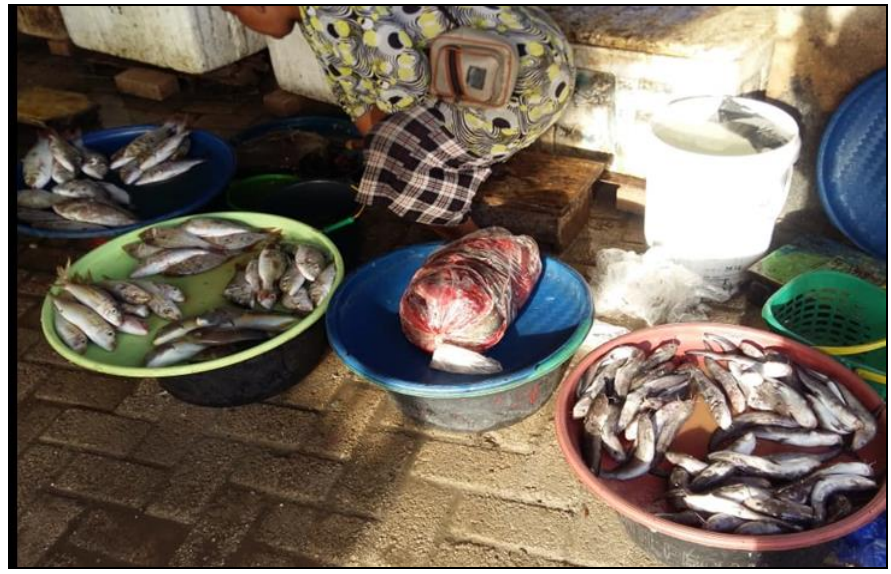

Figure 4. A portrait of a Bajo people selling the catch at Wanci Market

By in-depth observations made by researchers, it appears that most of the Bajo people also hold the distribution of work functions in their family life. For example, the fisher who are husbands has a duty to find food for the family, while the wife supported the household. Many 
housewives will wait for their husbands to come home from the sea by sitting in front of the house, looking at the boat, then welcoming the husband on the boat and taking the husband's catch, and they can manage the catch (there are some family that immediately get it to sell in the market, but there are also those that divide equally for households and to sell).

The development of adaptation in Bajo Mola society can be said to be in progress. The Bajo community stated that the past conditions were quite difficult, due to abundant sea products, but it has no price. Also, the low level of education and lack of government contribution has pushed the Bajo community to adapt to the sea. The current development demanded the Bajo people utilize natural products to obtain maximum profits. Some people started doing business with the technology and selling marine products, such as the grouper fishes. Also, there are other product processing innovations, especially tuna, namely loing technology. Loing technology is tuna processing technology by cutting with just taking the meat. The technology has been developing among Bajo people for the last five years.

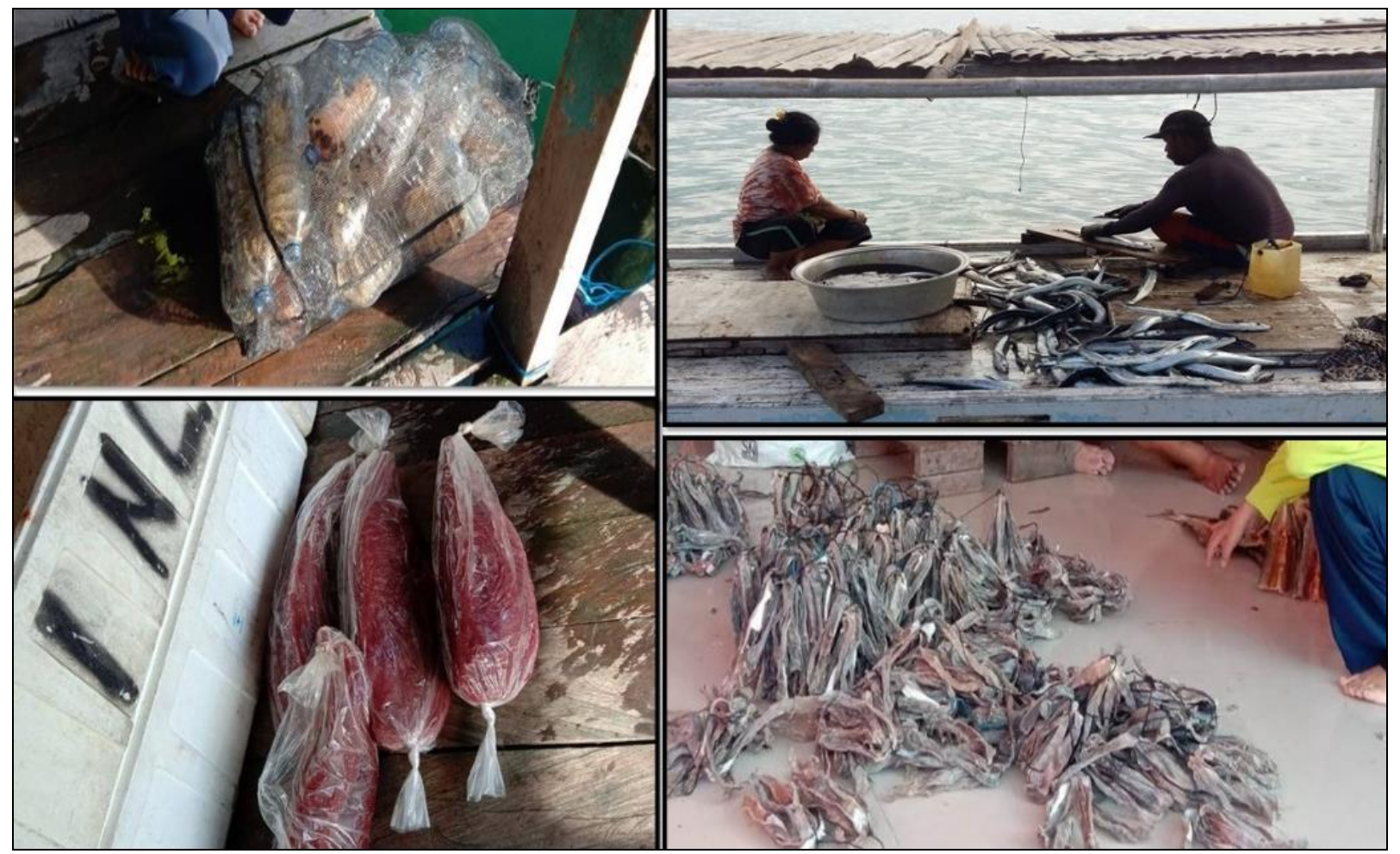

Figure 5. Portrait of the development of marine product management

At present, the adaptation of the Bajo Mola community tends to be more profitable with some of the activities carried out by entrepreneurs to encourage more productive economic activities. Farming grouper fishes, processing tuna, and dried squid or other fishes have an impact on the high amount of marine product production. The results of fisheries modification are then managed by entrepreneurs to be exported to other regions and even abroad, such as Korea and Japan. A successful entrepreneur from Bajo has brought the products abroad to prove that Bajo can use sea products other than just for daily needs.

The entire Bajo Mola community has not fully implemented the modifications made. There are only a few Bajo people who have assets can carry out these activities, though these activities have had a positive impact on the entire Bajo community. Bajo Mola fishers, who used to catch fish only for their daily needs, began to improve because the catch can be directly sold to collectors or directly sold to the market. The support from banks and interactions with communities outside Bajo also has pushed the economic activities in large-scale. Also, the development of fishing technology towards modernity makes it easier for the community to fishing.

The development of the Wakatobi region since 2003 has influenced the lives of Bajo people. Bajo people thought that the expansion of Wakatobi Regency would cause the price of fish to increase to gain more money from the sale. However, in practice, the catch and selling results are not balanced. If the catches are few, then the selling value is high, while the catches are high, the selling value will be small.

Other factors also influence the catches of fishermen, such as weather factors. For example, in the east season, the catch is just a few or inadequate, but the operation cost required a lot, such as the price of bait, fuel (using diesel). For example, on one trip required fuel (Solar) around 30-40 litters / 2 tanks with a diesel price of Rp. 75,000, so the total costs are around Rp. 200,000 - Rp. 300,000. In order to get balanced results, it takes at least 15 kilograms to sell for 70,000- Rp 75,000/kg. Having a similar profession in the Bajo community has made different economic impacts. Financial management factors are the main source of these differences. Often poor financial management becomes a problem that worsens the economic condition of the family.

The needs are extensive, accompanied by financial management that is less and more adding to the economic burden on society. Then, entrepreneurs have a significant role in improving the economy. Although it is not applied to the whole community, the presence of entrepreneurs can encourage more productive economic activities. The catches can be sold to the collectors or the business.

The adaptation of the Bajo Mola community from the economic side is quite extensive, such as support from the bank, easy access to marketing events, technology and innovation on aquaculture and fish prices that have sharply increased. The study concluded that the ecological adaptation of the Bajo Mola community in managing resources is aligned with the deterministic paradigm, as nature influences the lives of the community. However, the Bajo Mola community could continue to make innovation with existing technology (Neserism).

\section{CONCLUSION}

The adaptation strategy showed the unique adaptation of the Bajo people to make a house above the sea. From an economic point of view, it is known that the Bajo Mola people have a fairly high income as fishermen. Economic modernization has turned some professions to 
be businessmen and contributed to economic development. Due to the ease of buying and selling fishery products, getting funds from banks and the supports from every party have contributed significantly to improving the community's economy.

The study concluded that the selection of the Wakatobi as a National Park area could improve the socio-economic of Bajo Mola fishers life. However, there are restrictions on fishery activities in several zones, such as the Maritime Protection Zone. It also got support from other parties, such as banks, easy access to marketing, technology and innovations in aquaculture, and fish prices that have sharply increased.

\section{REFERENCES}

Artanto, K.Y. (2017). Bapongka, sistem budaya suku Bajo in maintaining Kelestarian Sumber Daya Pesisir [Bapongka, Bajo Cultural System in Maintaining the Sustainability of Coastal Resources]. (in Malay), Sabda, 12(1), 52-69. https://ejournal.undip.ac.id/index.php/sabda/article/view/15253

Bahtiar. (2012). The Local Genius Applied by the Bajo People to Managing Sea Sources. Mudra, 2(2), $178-85$.

Bakker, SJ.J.W.M. (1984). Filsafat Kebudayaan, Suatu Pengantar. [Cultural Philosophy, An Introduction]. Yogyakarta. Penerbit, Yayasan Kanisius.

Bennett, N.J. (2019). Marine social science for the peopled seas. Coastal Management, 47(2), 244-252. https://doi.org/10.1080/08920753.2019.1564958

Cisneros-Montemayor, A.D., Pauly, L., Weatherdon., \& Ota, Y. (2016). A global estimate of seafood consumption by coastal indigenous peoples. PLoS One 11(12), e0166681. https://doi.org/10.1371/journal.pone.0166681

Dirhamsyah. (2016). Setbacks in the development of marine protected areas in Indonesia. Australian Journal of Maritime \& Ocean Affairs, 8(2), 87-100. https://doi.org/10.1080/18366503.2016.1187781

Fatchan. (2015). Metode Penelitian Kualitatif Pendekatan Etnografi dan Etnometodologi untuk Penelitian Ilmu-Ilmu Sosial [Qualitative Research Methods with Ethnographic and Ethnometodological Approaches for Research in Social Sciences]. Yogyakarta. Ombak.

Firmansyah, F., Musthofa, A., Estradivari, Damora, A., Handayani, C. Ahmadia, G. \& Jill H. (2016). Satu dekade pengelolaan Taman Nasional Wakatobi: Keberhasilan dan tantangan konservasi laut. [A decade of management of Wakatobi National Park: Successes and challenges of marine conservation]. WWF-ID, Jakarta, Indonesia. https://www.researchgate.net/publication/322853835_Satu_Dekade_Pengelolaan_Taman_Nasional_Wakatobi_Keberhasilan_ dan_Tantangan_Konservasi_Laut

Geertz, H. (1981). Aneka budaya dan komunitas di Indonesia. [Various Cultures and Communities in Indonesia]. Jakarta: Yayasan Ilmu-Ilmu Sosial \& FS UI.

Khasanah, M., Nurdin, N., Mitcheson, Y.S.D., \& Jompa, J. (2020). Management of the Grouper Export Trade in Indonesia. Reviews in Fisheries Science \& Aquaculture, 28(1), 1-15. https://doi.org/10.1080/23308249.2018.1542420

Koentjaraningrat. (1990). Beberapa Pokok Antropologi Sosial [The Fundamental of Socio Anthropology]. Jakarta, PT. Dian Rakyat.

Lewin, W.C., Weltersbach, M. S., Ferter, K., Hyder, K., Mugerza, E., Prellezo, R., \& Strehlow, H.V. (2019). Potential environmental impacts of recreational fishing on marine fish stocks and ecosystems. Reviews in Fisheries Science \& Aquaculture, 27(3), 287-330. https://doi.org/10.1080/23308249. 2019.1586829

Marlina, Sumarmi, \& Astina, I.K. (2020). Sustainable Marine Ecotourism Management: A Case of Marine Resource Conservation Based on Local Wisdom of Bajo Mola Community in Wakatobi National Park. GeoJournal of Tourism and Geosites, 32(4), 1317-1323. https://doi.org/10.30892/gtg.32419-575

Moeis, S. (2008). Adaptasi Ekologi Masyarakat Pesisir Selatan Jawa Barat Suatu Analisis Kebudayaan. [Ecological Adaptation of the South Coastal Communities of West Java A Cultural Analysis]. Makalah disajikan dalam Diskusi Jurusan Pendidikan Sejarah.

Moleong, \& Lexi J. (2016). Metode Penelitian Kualitatif [Qualititive Research Methodology], Bandung: PT Remaja Rosdakarya.

Sopari, H., Oka, N.P., \& Salman, D. (2014). Model Kolaborasi Perencanaan antara Balai Taman Nasional Wakatobi dan Pemerintah Kabupaten Wakatobi dalam Pengelolaan Sumber Daya Alam Hayati secara Lestari. [Planning Collaboration Model between Wakatobi National Park Office and Wakatobi Regency Government in Sustainable Management of Living Natural Resources]. J Sains \& Teknologi, 14(2), 189-198. http://pasca.unhas.ac.id/ jurnal/files/827db9e2d02070326ee7240b9c2289b3.pdf

Sumarmi, Kurniawati, E., \& Aliman, M. (2020). Community-Based Tourism (Cbt) to Establish Blue Economy and Improve Public Welfare for Fishing Tourism Development in Klatak Beach, Tulungagung, Indonesia. GeoJournal of Tourism and Geosites, 31(3), 979-986. https://doi.org/10.30892/gtg.31307-530

Turak, E. (2003). Coral reef surveys during. TNC SEACMPA RAP of Wakatobi National Park, Southeast Sulawesi, Indonesia. Bali, The Nature Conservancy.

Wani, K.A., \& Ariana, L. (2018). Impact of climate change on indigenous people and adaptive capacity of bajo tribe, Indonesia. Environmental Claims Journal, 30(4), 302-313. https://doi.org/10.1080/10406026.2018.1504380

*** BMKG. (2020). Prakiraan Cuaca Sulawesi Tenggara-Indonesia [Weather forecast of Southeast Sulawesi Indonesia]. BMKG, Badan Meteorologi, Klimatologi, dan Geofisika [Meteorology Climatology and Geophysics Council]. https://www.bmkg.go.id/cuaca/prakiraancuacaindonesia.bmkg? Prov=30\&NamaProv=Sulawesi Tenggara

*** BPS. (2019). Wakatobi dalam angka. Badan Pusat Statistik Kabupaten Wakatobi [Central Bureau of Statistics in Wakatobi Regency] https://wakatobikab.bps.go.id/publication.html

*** BPS. (2020). Wakatobi dalam angka. Badan Pusat Statistik Kabupaten Wakatobi [Central Bureau of Statistics of Wakatobi Regency]. https://Wakatobikab.bps.go.id/publication.html.

*** UNESCO. (2012). Ecological Sciences for Sustainable Development. United Nations Educational, Scientific and Cultural Organization, http://www.unesco.org/new/en/naturalsciences/environment/ecologicalsciences/biosphere-reserves/asia-and-the-pacific/indonesia/wakatobi/

*** United Nations. (2017). Factsheet: People and oceans. New York: United Nations.

$\begin{array}{lll}\text { Article history: } & \text { Received: } 11.07 .2020 & \text { Revised: 04.11.2020 }\end{array}$
Available online: 07.01.2021 